Đuro Jovanić, poručnik, dipl. oec.

VP 3065-6

Sombor

\section{TESTIRANJE BALISTIČKE OTPORNOSTI ZAŠTITNIH PRSLUKA}

\author{
UDC: $623.445 .1: 006$
}

Rezime:

U radu je predstavljena osnova standarda NIJ 0101.04 (Nacionalni Institut Pravde), namenjenog za utvrdivanje minimuma tehničkih zahteva i propisivanje metoda ispitivanja balističke otpornosti zaštitnih prsluka, koji treba da zaštite gornji deo tela od dejstva streljačkog oružja. Standard jeste revizija standarda NIJ 0101.03 iz aprila 1987. i preciznije definiše zahteve u pogledu obeležavanja, kriterijume za prijem i postupke merenja otiska u materijalu iza prsluka. Područje ovog standarda odnosi se samo na balističku otpornost, ali ne $i$ na pretnje od noža i predmeta sa oštrim vrhom. Takođe, ne odnosi se na zaštitne prsluke koji sadrže dopunske elemente ili varijacije u konstrukciji balističkih panela za malu površinu torza, radi povećanja osnovnog nivoa zaštite na ograničenim površinama (bilo balističke ili povrede od tupog vrha).

Ključne reči: upadni ugao, penetracija, ispravan pogodak, deformacija, zaštitni prsluk, uzorak.

\title{
BALLISTIC RESISTANCE OF BODY ARMOUR TESTING
}

Summary:

This work is a basic presentation of NIJ 0101.04 (National Institute of Justice) standard, whose purpose is to establish minimum performance requirements and methods of testing ballistic resistance of body armor intended to protect the torso against gunfire. This standard is a revision of NIJ Standard 0101.03 dated April 1987 and it clarifies the labeling requirements, acceptance criteria, and backface signature measurement procedure. The scope of this standard is limited only to ballistic resistance; and it does not include threats from knives and sharply pointed instruments. In addition, the standard does not include armor that incorporates inserts, or variations in construction of the ballistic panel over small areas of the torso, used for increasing the basic level of protection of the armor (whether ballistic or blunt trauma) on localized areas.

Key words: angle of incidence, penetration, fair hit, deformation, body armour, sample.

\section{Uvod}

Potreba za preciznim utvrđivanjem balističke otpornosti zaštitnih prsluka, minimuma tehničkih zahteva koje moraju ispuniti, razgraničavanjem vidova pretnji (balistička otpornost, zaštita od hladnog oružja), kao i pomoći pri nabavci opreme koja treba da zaštiti gornji deo tela od dejstva streljačkog oružja, uslovi- la je propisivanje standarda za ovo specifično područje primene. Pojedini standardi koji danas važe, mogu uneti nejasnoce, propisujući neadekvatne uslove o metodama testiranja, balističkoj otpornosti i nivou zaštite koja se pruža krajnjim korisnicima.

Upravo zbog nedoumica koje se javljaju, nabavne službe vodećih armija sveta odlučuju se za zaštitne prsluke koji 
ispunjavaju zahteve propisane standardima poput GSS (German Standard Schutzklasse), AS/NZS (Australian and New Zeland Standard), ali generalno najčešće za zaštitne prsluke akreditovane najpouzdanijim standardom NIJ (National Institute of Justice).

Standard NIJ formulisala je Laboratorija za standarde bezbednosti 1972. godine, u Nacionalnom birou za standarde pod upravom Ministarstva pravde SAD, pri Programu ocenjivanja tehnologija visokog kvaliteta. Tehnička istraživanja izvode se pri Laboratoriji za hemijske sisteme, na opitnom poligonu armije SAD u Aberdeenu. Do danas je nastao veliki broj modifikacija i dopuna ovog standarda, tako da i dalje, radi sveopšte bezbednosti krajnjih korisnika, podleže stalnom preispitivanju i usavršavanju.

Standard koji predstavlja polaznu osnovu za precizno testiranje balističke otpornosti zaštitnih prsluka nosi oznaku NIJ 0101.04 i odnosi se na balističku otpornost, kriterijume za prijem, postupke merenja otiska u materijalu iza prsluka i zahteve vezane za obeležavanje zaštitnih prsluka. Ovaj standard ne odnosi se na prsluke koji služe za zaštitu od noža i predmeta sa oštrim - tupim vrhom, jer su to drugačiji vidovi pretnji, kao i zaštitne prsluke koji sadrže dopunske elemente ili varijacije u konstrukciji balističkih panela za malu površinu torza, radi povećanja osnovnog nivoa zaštite na ograničenim površinama.

\section{Klasifikacija balističkih zaštitnih prsluka}

Zaštitni prsluci obuhvaćeni standardom NIJ-0101.04 klasifikuju se u 7 razli- čitih tipova (stepena), u zavisnosti od nivoa balističkih zaštitnih osobina, i to na:

- tip I (.22 LR, .380 ACP) štiti od olovnog zrna kal. .22 LR LRN, nominalne mase 2,6 g (40 gr), pri udarnoj brzini od $320 \mathrm{~m} / \mathrm{s}(1050 \mathrm{ft} / \mathrm{s})$ ili manjoj i od .380 ACP FMJ RN nominalne mase 6,2 g (95 gr), koji ima udarnu brzinu od 312 $\mathrm{m} / \mathrm{s}(1025 \mathrm{ft} / \mathrm{s})$ ili manju;

- tip II-A (9 mm; $40 \mathrm{~S} \& W)$ štiti od zrna 9 mm FMJ RN, nominalne mase 8,0 g (124 gr), pri udarnoj brzini od $332 \mathrm{~m} / \mathrm{s}$ $(1090 \mathrm{ft} / \mathrm{s})$ ili manjoj i $40 \mathrm{~S} \& W$ FMJ zrna nominalne mase $11,7 \mathrm{~g}$ (180 gr), čija je udarna brzina $312 \mathrm{~m} / \mathrm{s}(1025 \mathrm{ft} / \mathrm{s})$ ili manja, kao i od pretnji navedenih za tip I;

- tip II (9 mm; 357 Magnum) štiti od zrna 9 mm FMJ RN nominalne mase $8,0 \mathrm{~g}$ (124 gr), čija je udarna brzina 358 $\mathrm{m} / \mathrm{s}(1175 \mathrm{ft} / \mathrm{s})$ ili manja i 357 Magnum JSP zrna nominalne mase od 10,2 g (158 gr), čija je udarna brzina od $427 \mathrm{~m} / \mathrm{s}$ (1400 ft/s) ili manja.Takođe, obezbeđuje zaštitu od pretnji koje su napomenute za tip I i II-A;

- tip III-A (9 mm; 44 Magnum većih brzina) štiti od olovnih zrna $9 \mathrm{~mm}$ FMJ RN, nominalne mase 8,0 g (124 gr), čija je udarna brzina $427 \mathrm{~m} / \mathrm{s}(1400 \mathrm{ft} / \mathrm{s})$ ili manja i 44 Magnum SJHP zrna nominalne mase od 15,6 g (240 gr), čija je udarna brzina od $427 \mathrm{~m} / \mathrm{s}(1400 \mathrm{ft} / \mathrm{s})$ ili manja. Takođe, obezbeđuje zaštitu od najvećeg broja zrna koja su ispaljena iz pištolja i revolvera, kao i od pretnji za tip I, II-A i II;

- tip III (puške velike moći) štiti od zrna 7,62 mm FMJ (U.S. vojne oznake M80) nominalne mase 9,6 g (148 gr), čija je udarna brzina $838 \mathrm{~m} / \mathrm{s}(2750 \mathrm{ft} / \mathrm{s})$ ili manja. Takođe, obezbeđuje zaštitu od pretnji pomenutih za tip I, II-A, II i III-A; 
- tip IV (puške za proboj oklopa) štiti od zrna cal.30 AP (U.S. vojne oznake M2 AP) nominalne mase 10,8 g (166 gr), čija je brzina $869 \mathrm{~m} / \mathrm{s}(2850 \mathrm{ft} / \mathrm{s})$ ili manja. Takođe, obezbeđuje zaštitu od najmanje jedne vrste zrna, koja su navedena za tip I, II-A, II, III-A i III.

- specijalni tip, pruža ispunjenje specijalnih zahteva krajnih korisnika, za nivo zaštite koji je viši od definisanog standardom NIJ 0101.04, a pre testiranja je potrebno tačno da se navede od kojih zrna je potrebna zaštita. Nijedan ispravan pogodak ili zrno pri brzinama manjim od minimalno zahtevanih ne sme da probije prsluk.

U tabeli 1 prikazano je značenje skraćenica korišćenih pri definisanju tipova zaštitnih prsluka.

Tabela 1

\begin{tabular}{|c|c|c|}
\hline LRN & Lead Round Nose & Potpuno olovno zrno \\
\hline FMJ RN & $\begin{array}{c}\text { Full Metal Jacketed } \\
\text { Round Nose }\end{array}$ & $\begin{array}{c}\text { zrno sa potpunom } \\
\text { metalnom košuljicom }\end{array}$ \\
\hline JSP & Jacketed Soft Point & $\begin{array}{c}\text { zrno sa mekanom } \\
\text { košuljicom }\end{array}$ \\
\hline SJHP & $\begin{array}{c}\text { Semi Jacketed } \\
\text { Hollow Point }\end{array}$ & $\begin{array}{c}\text { zrno sa polumekanom } \\
\text { košuljicom } \\
\text { i zaobljenim vrhom }\end{array}$ \\
\hline AP & armor piercing & pancirno zrno \\
\hline
\end{tabular}

Važno je imati u vidu da balistička otpornost od nekog zrna generalno zavisi od njegovog sastava, oblika, kalibra, ma- se, upadnog ugla i udarne brzine. Međutim, zbog širokog asortimana municije koja se može dobiti u određenom kalibru, kao i zbog postojanja ručno punjene municije, prsluci koji štite od standardnih test-zrna ne moraju da štite od municije istog kalibra, a drugog punjenja. Tako da, na primer, prsluk koji sprečava penetraciju standardnog zrna $40 \mathrm{~S} \& \mathrm{~W}$ može, ali ne mora, da štiti od zrna $40 \mathrm{~S} \& W$ većih brzina. Uopšte, neki prsluk koji štiti od datog olovnog zrna ne mora da bude otporan na penetraciju drugih zrna u istom kalibru, ali različite konstrukcije ili oblika.

\section{Definicije}

Upadni ugao je ugao između linije putanje leta zrna i normale na tangentu ravni do tačke udara zrna (slika 1).

Materijal za pozadinu predstavlja blok od plastelina za modeliranje, na bazi ulja, postavljen tako da bude u kontaktu sa zadnjom stranom ispitivanog uzorka prsluka za sve vreme balističkog ispitivanja.

Deformacija je maksimalno trenutno istiskivanje zadnje strane uzorka prsluka koji se ispituje, izazvano ispravnim pogotkom koji ne prodire kroz uzorak kada je $\mathrm{u}$ početnom kontaktu sa plastelinom.

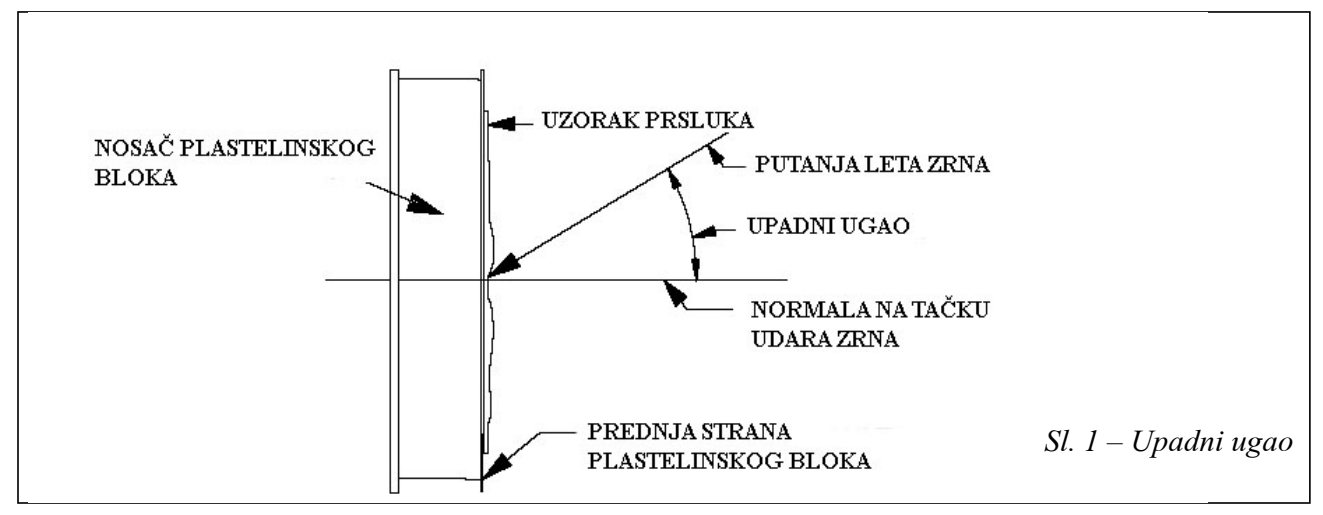


Dubina otiska je rastojanje mereno na materijalu za pozadinu od osnovne neporemećene površine, do najniže tačke otiska.

Ispravan pogodak je onaj koji pogađa prsluk pod upadnim uglom ne većim za $\pm 5^{\circ}$ od planiranog upadnog ugla, ne bliže ivici prsluka od $76 \mathrm{~mm}(3,0$ in) i ne bliže prethodnom pogotku (mereno od centra do centra pogotka) na rastojanju od $51 \mathrm{~mm}$ (2,0 in), pri udarnoj brzini koja nije veća za $50 \mathrm{ft} / \mathrm{s}(15 \mathrm{~m} / \mathrm{s})$ od najmanje zahtevane brzine za testiranje.

Proboj (penetracija) ispitivanog uzorka prsluka sa ispitivanim zrnom ili fragmentom zrna ili fragmentom panela, očitava se prisustvom zrna ili fragmenta u plastelinu ili postojanjem rupe u plastelinu.

\section{Pripreme za ispitivanje balističke otpornosti zaštitnih prsluka}

Pre početka ispitivanja balističke otpornosti potrebno je izvršiti uzorkovanje metodom slučajnih uzoraka, izdvajanjem određenog broja kompletnih prsluka, u zavisnosti od stepena zaštite za koji se vrši testiranje. Svaki izdvojeni prsluk treba da bude bez: nabora, mehurova, izbočina, prskotina ili poderotina (tekstilnih), pukotina, odsečaka, oštrih uglova ili drugih oštećenja.

Važno je uzeti u obzir da što je veća veličina uzorka, to je veća verovatnoća da se balističko testiranje okonča na manjem broju kompletnih prsluka.

\section{Uzorkovanje:}

- za tip I, II-A, II, III-A izdvaja se šest kompletnih prsluka u veličinama koje odgovaraju obimu grudi od $117 \mathrm{~cm}$ (46 in) do $122 \mathrm{~cm}$ (48 in) za muškarce i veli- činama koje odgovaraju obimu grudi od $107 \mathrm{~cm}$ (42 in) do $112 \mathrm{~cm}$ (44 in) za žene;

- za tip III izdvajaju se četiri kompletna prsluka ili panela, koji ne smeju biti manji od $254 \mathrm{~mm} \times 305 \mathrm{~mm}(10,0$ in $\times 12,0$ in);

- za tip IV izdvaja se devet kompletnih prsluka, uzoraka-panela-umetaka, koji ne smeju biti manji od $203 \mathrm{~mm} \times$ $254 \mathrm{~mm}(8,0$ in $\times 10,0$ in $)$.

\section{Kondicioniranje vlažnog prsluka}

Kompletan prsluk treba da se kondicionira tako što se obe strane (svakog dela prsluka) podvrgavaju dejstvu vode koja prska pod sledećim uslovima:

- sprej - mlaznica treba da bude takve veličine i postavljena tako da 100 $\mathrm{mm} / \mathrm{h} \pm 20 \mathrm{~mm} / \mathrm{h}(4,0 \mathrm{in} / \mathrm{h} \pm 0,8 \mathrm{in} / \mathrm{h}) \mathrm{ka}-$ pljica vode padne u uniformnom rasporedu na obe strane prsluka;

- mlaznicu orijentisati tako da kada dođe do udara kapljica u površinu prsluka, nastane njihovo slivanje usled dejstva sile gravitacije;

- temperatura vode na izlazu iz mlaznice treba da iznosi od $10^{\circ} \mathrm{C}$ do $21^{\circ} \mathrm{C}$ $\left(50^{\circ} \mathrm{F}\right.$ do $\left.70^{\circ} \mathrm{F}\right)$;

- kompletan zaštitni prsluk, uključujući i odvojive delove, kondicira se 6 minuta;

- poslednja se prska udarna strana prsluka (Strike face) u intervalu od $3 \mathrm{mi}$ nuta.

Ako usled nedostatka odgovarajućih uslova ne mogu da se kondicioniraju kompletni prsluci, onda se pristupa kondicioniranju minimalne površine prsluka od $762 \mathrm{~mm} \times 762 \mathrm{~mm}(30,0$ in $\times 30,0$ in $)$ koja će omogućiti dalje uspešno testiranje. 


\section{Materijal za pozadinu}

Da bi se mogla precizno izmeriti deformacija, nastala posle udara zrna u uzorak, potrebno je iza njega postaviti odgovarajući materijal, na kojem će biti moguće izmeriti nastali otisak. Taj materijal treba da bude u obliku bloka plastelina debljine 25 $\mathrm{mm}(1,0 \mathrm{in})$ do $51 \mathrm{~mm}$ (2,0 in), širine i dužine $254 \mathrm{~mm} \times 254 \mathrm{~mm}(10,0$ in $\times 10,0$ in $) i$ kao takav je dovoljan za kompletno naslanjanje dela prsluka koji se ispituje. Potrebno je da bude bez šupljina i kondicionira najmanje $3 \mathrm{~h}$, na temperaturi između $15^{\circ} \mathrm{C}$ i $30^{\circ}$ $\mathrm{C}\left(59^{\circ} \mathrm{F}\right.$ i $\left.95^{\circ} \mathrm{F}\right)$.

Konzistencija ovog materijala treba da bude takva da se nakon pada sa visine od $2,0 \mathrm{~m}(6,56 \mathrm{ft})$ čeličnog tega cilindričnog oblika (mase $1043 \mathrm{~g} \pm 5 \mathrm{~g}(2,29 \mathrm{lb} \pm 0,01$ lb)), prečnika $63,5 \mathrm{~mm} \pm 0,05 \mathrm{~mm}(2,5 \mathrm{in} \pm$ 0,001 in) i poluloptastog oblika na udarnom kraju, na jednoj strani plastelina kvadratnog oblika postigne debljina ulegnuća (otiska) od $19 \mathrm{~mm} \pm 2 \mathrm{~mm}(0,748 \mathrm{in} \pm 0,08 \mathrm{in})$.

Potrebno je uraditi pet ovakvih testiranja na pad tega, s tim da centar svakog mesta udara bude najmanje $152 \mathrm{~mm}(6,0 \mathrm{in})$ udaljen od centra prethodnog udara i 76 $\mathrm{mm}(3,0$ in) od svake ivice plastelinskog bloka (slika 2). Plastelin može biti na bilo kojoj temperaturi $\mathrm{u}$ navedenom rasponu, pod uslovom da daje traženu konzistenciju.

Za prsluke koji su po veličini i obliku namenjeni ženama izrađuju se korpe za grudi napunjene plastelinom, kondicioniranim zajedno sa plastelinom za po-

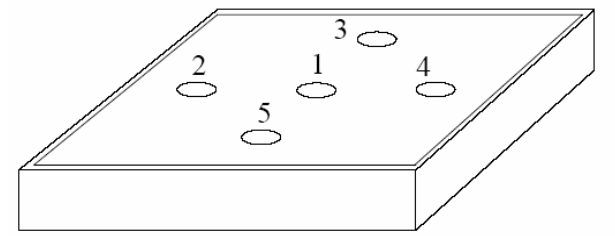

Sl. 2 - Testiranje konzistencije materijala za pozadinu stavljanje iza prsluka i na isti način. Pri testiranju otiska u materijalu za pozadinu ovakvog prsluka, na posebno oblikovane korpe ne ispušta se čelični teg, već se to vrši u njihovoj blizini.

Materijal za pozadinu postavlja se na nosač plastelinskog bloka koji je izrađen od drveta unutrašnjih dimenzija 610 $\times 610 \times 140 \mathrm{~mm} \pm 2 \mathrm{~mm}(24,0$ in $\times 24,0$ in $\times 5,5$ in $\pm 0,06$ in). Dozvoljene tolerancije pri izradi nosača plastelinskog bloka su $\pm 2 \mathrm{~mm}( \pm 0,06$ in $)$.

Pre početka testiranja potrebno je izvaditi iz kondicioniranog prsluka sve uklonive umetke, osim zaštitnog.

\section{Učvršćivanje uzoraka}

Uzorak zaštitnog prsluka potrebno je postaviti na materijal za pozadinu, tako da zauzima vertikalni položaj u odnosu na cev za testiranje. Radi što boljeg učvršćivanja i naleganja uzorka prsluka koristi se elastično-lepljiva traka širine $51 \mathrm{~mm}$, kao što je to prikazano na slici 3 .

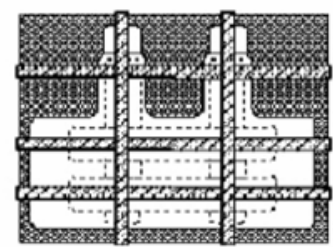

fiksiranje pomoću elastičnih traka

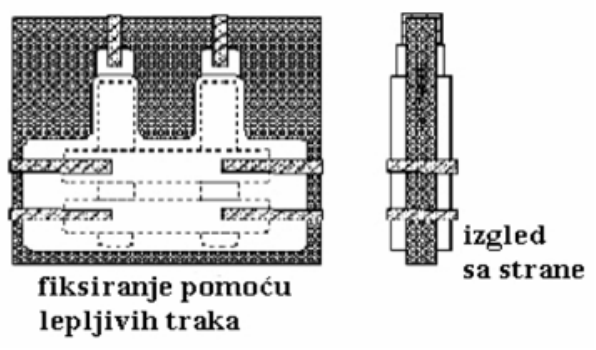

Sl. 3 - Učvršćivanje uzorka prsluka pomoću elastično-lepljive trake 
Zahtevi za ispitivanje otpornosti zaštitnih balističkih prsluka prema standardu NIJ 0101.04

\begin{tabular}{|c|c|c|c|c|c|c|c|c|c|c|c|}
\hline \multicolumn{5}{|c|}{ Parametri ispitivanja } & \multicolumn{7}{|c|}{ Zahtevane performanse } \\
\hline 1. & 2. & 3. & 4. & 5. & 6. & 7. & 8. & 9. & 10. & 11. & 12. \\
\hline 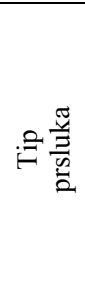 & 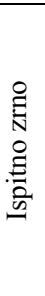 & $\begin{array}{c}\text { Ispitna } \\
\text { municija }\end{array}$ & $\begin{array}{l}\text { Masa } \\
\text { zrna }\end{array}$ & $\begin{array}{c}\text { Min. } \\
\text { potrebna } \\
\text { brzina } \\
\text { zrna } \\
( \pm 30 \mathrm{ft} / \mathrm{s})\end{array}$ & 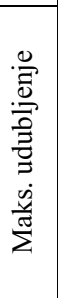 & 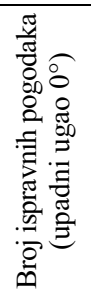 & 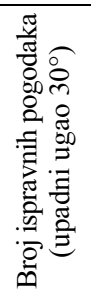 & 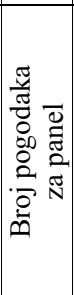 & 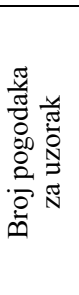 & 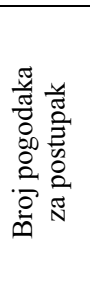 & 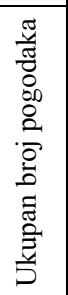 \\
\hline \multirow[t]{2}{*}{ I } & 1 & $\begin{array}{c}.22 \text { caliber } \\
\text { LR } \\
\text { LRN }\end{array}$ & $\begin{array}{l}2,6 \mathrm{~g} \\
40 \mathrm{gr} .\end{array}$ & $\begin{array}{c}329 \mathrm{~m} / \mathrm{s} \\
(1080 \mathrm{ft} / \mathrm{s})\end{array}$ & \multirow{11}{*}{ 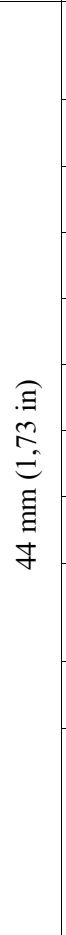 } & 4 & 2 & 6 & 12 & 24 & \multirow[t]{2}{*}{48} \\
\hline & 2 & $\begin{array}{l}.380 \mathrm{ACP} \\
\text { FMJ RN }\end{array}$ & $\begin{array}{l}6,2 \mathrm{~g} \\
95 \mathrm{gr} .\end{array}$ & $\begin{array}{c}322 \mathrm{~m} / \mathrm{s} \\
(1055 \mathrm{ft} / \mathrm{s})\end{array}$ & & 4 & 2 & 6 & 12 & 24 & \\
\hline \multirow{2}{*}{ II-A } & 1 & $\begin{array}{c}9 \mathrm{~mm} \\
\text { FMJ RN }\end{array}$ & $\begin{array}{c}8,0 \mathrm{~g} \\
124 \mathrm{gr} .\end{array}$ & $\begin{array}{c}341 \mathrm{~m} / \mathrm{s} \\
(1120 \mathrm{ft} / \mathrm{s})\end{array}$ & & 4 & 2 & 6 & 12 & 24 & \multirow{2}{*}{48} \\
\hline & 2 & $\begin{array}{c}40 \mathrm{~S} \& \mathrm{~W} \\
\text { FMJ }\end{array}$ & $\begin{array}{l}11,7 \mathrm{~g} \\
180 \mathrm{gr} .\end{array}$ & $\begin{array}{c}322 \mathrm{~m} / \mathrm{s} \\
(1055 \mathrm{ft} / \mathrm{s})\end{array}$ & & 4 & 2 & 6 & 12 & 24 & \\
\hline \multirow{2}{*}{ II } & 1 & $\begin{array}{c}9 \mathrm{~mm} \\
\text { FMJ RN }\end{array}$ & $\begin{array}{c}8,0 \mathrm{~g} \\
124 \mathrm{gr} .\end{array}$ & $\begin{array}{c}367 \mathrm{~m} / \mathrm{s} \\
(1205 \mathrm{ft} / \mathrm{s})\end{array}$ & & 4 & 2 & 6 & 12 & 24 & \multirow{2}{*}{48} \\
\hline & 2 & $\begin{array}{l}357 \mathrm{Mag} \\
\text { JSP }\end{array}$ & $\begin{array}{l}10,2 \mathrm{~g} \\
158 \text { gr. }\end{array}$ & $\begin{array}{c}436 \mathrm{~m} / \mathrm{s} \\
(1430 \mathrm{ft} / \mathrm{s})\end{array}$ & & 4 & 2 & 6 & 12 & 24 & \\
\hline \multirow{2}{*}{ III-A } & 1 & $\begin{array}{c}9 \mathrm{~mm} \\
\text { FMJ RN }\end{array}$ & $\begin{array}{c}8,2 \mathrm{~g} \\
124 \mathrm{gr} .\end{array}$ & $\begin{array}{c}436 \mathrm{~m} / \mathrm{s} \\
(1430 \mathrm{ft} / \mathrm{s})\end{array}$ & & 4 & 2 & 6 & 12 & 24 & \multirow{2}{*}{48} \\
\hline & 2 & $\begin{array}{l}44 \mathrm{Mag} \\
\text { SJHP }\end{array}$ & $\begin{array}{l}15,6 \mathrm{~g} \\
240 \text { gr. }\end{array}$ & $\begin{array}{c}436 \mathrm{~m} / \mathrm{s} \\
(1430 \mathrm{ft} / \mathrm{s})\end{array}$ & & 4 & 2 & 6 & 12 & 24 & \\
\hline III & 1 & $\begin{array}{c}7.62 \mathrm{~mm} \\
\text { NATO } \\
\text { FMJ }\end{array}$ & $\begin{array}{c}9,6 \mathrm{~g} \\
148 \text { gr. }\end{array}$ & $\begin{array}{c}847 \mathrm{~m} / \mathrm{s} \\
(2780 \mathrm{ft} / \mathrm{s})\end{array}$ & & 6 & 0 & 6 & 12 & 12 & 12 \\
\hline IV & 2 & $\begin{array}{l}.30 \text { caliber } \\
\text { M2 AP }\end{array}$ & $\begin{array}{c}10,8 \mathrm{~g} \\
166 \text { gr. }\end{array}$ & $\begin{array}{c}878 \mathrm{~m} / \mathrm{s} \\
(2880 \mathrm{ft} / \mathrm{s})\end{array}$ & & 1 & 0 & 1 & 2 & 2 & 2 \\
\hline 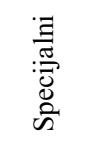 & $*$ & * & * & * & & * & * & * & * & * & * \\
\hline ve & & da na & кup & i podac & . & $a b$ & de & 1115 & $\mathrm{~h}$ is & 11 & k ili \\
\hline
\end{tabular}

Položaj uzorka obeležava se na materijalu za pozadinu, trasiranjem pomoću vrha olovke ili sličnog alata, radi preciznog utvrđivanja njegovog položaja posle izlaganja penetraciji i deformaciji nastalih za vreme testiranja.

\section{Ispitno oružje i municija}

Oružje za ispitivanje može da bude pištolj, revolver, automat, puška ili opitna cev ANSI/SAAMI sa komorom za zrna od kojih ispitivani tip prsluka treba da 
pruži zaštitu. Ispitna municija se klasifikuje prema detaljnim zahtevima za ispitivanje otpornosti zaštitnih balističkih prsluka prema standardu NIJ 0101.04, koji su prikazani u tabeli 2 .

Za određena testiranja može da se zahteva i ručno laborisana municija, radi postizanja zahtevane brzine za određeni tip balističkog zaštitnog prsluka.

Opremu za testiranje treba postaviti na način prikazan na slici 4, vodeći računa da se cev za testiranje nalazi u horizontalnom položaju. Elektronska oprema treba da se zagreje do radne temperature, koju propisuje proizvođača za svaki uređaj. Prostoriju za testiranje treba zagrejati i održavati na temperaturi od $21^{\circ} \mathrm{C}$ $\pm 2,9^{\circ} \mathrm{C}\left(70^{\circ} \mathrm{F} \pm 5^{\circ} \mathrm{F}\right)$ i relativnoj vlažnosti vazduha od $50 \% \pm 20 \%$.

Svaki put pre i nakon ispaljivanja serije test-municije potrebno je izmeriti temperaturu i vlažnost prostorije za testiranje. Da bi sa sigurnošću znali da će prvo test-zrno pogoditi prsluk brzinom koja nije veća za $15 \mathrm{~m}(50 \mathrm{ft})$ u sekundi od najniže zahtevane brzine za test-zrno, potrebno je ispaliti dovoljan broj probnih zrna pre testiranja.

Poslednje zrno pre testiranja ispaljuje se tako da prođe kroz karton, radi određivanja njegove putanje i mesta pogotka. Alternativno, može se upotrebiti snop svetla nišanske sprave ili drugog pogodnog sredstva za nišanjenje i obeležavanje tačke udara zrna.

U slučaju da karton koji je korišćen pre testiranja ostane, uzorak prsluka treba postaviti tako da željeno mesto narednog pogotka dodiruje rupu u kartonu od pogotka pre testiranja, a zatim ukloniti karton.

Prvu barijeru START-TRIGGER, vezanu za hronograf, treba postaviti tako

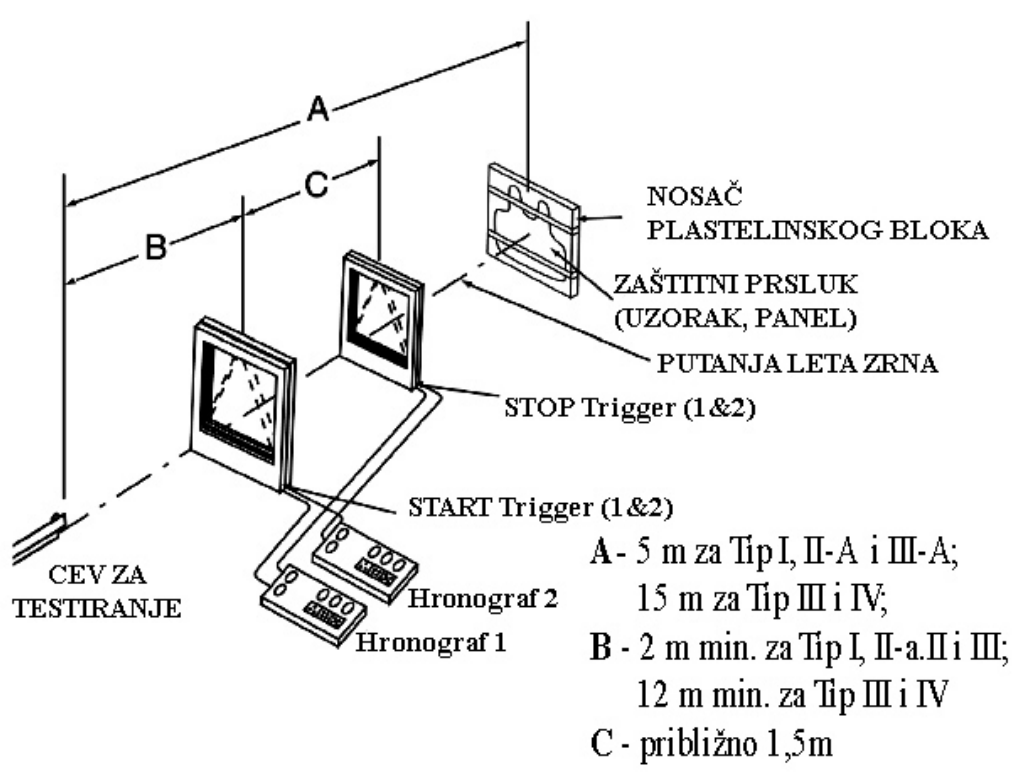

Sl. 4 - Izgled postavljene opreme za testiranje balističke otpornosti prsluka 
da bude udaljena najmanje $2 \mathrm{~m}(6,6 \mathrm{ft})$ od usta cevi za testiranje, a drugu barijeru (STOP-TRIGGER) na rastojanje od prve približno za $1,5 \mathrm{~m}(4,9 \mathrm{ft})$. Barijere treba postaviti tako da obrazuju ravni normalne na liniju putanje leta zrna.

Rastojanje izmedu njih treba izmeriti sa preciznošću od $1 \mathrm{~mm}(0,04$ in), a rastojanje do barijera A i B, meri se od usta cevi za testiranje sa preciznošću od \pm 25 $\mathrm{mm}( \pm 1,0$ in $)$.

\section{Testiranje balističke otpornosti}

Komletan uzorak prsluka (svaki njegov deo) treba da se testira na otpornost prema balističkoj penetraciji i balističkoj deformaciji, odmah posle vlažnog kondicioniranja. Celokupno testiranje uzorka prsluka mora da se obavi u roku od 30 minuta. Ovo vreme se računa od momenta uklanjanja prsluka ispod spreja - mlaznice.

Prvo testiranje ispitnom municijom treba da se završi za 10 minuta. U slučaju da testiranje nije kompletno završeno $u$ predviđenom intervalu, rezultati ispitivanja se odbacuju, a drugo testiranje vlažnog uzorka mora da se ponovi sa novim prslukom.

Proboj ostvaren svakim ispravnim pogotkom, tj. svaka deformacija do dubine veće od $44 \mathrm{~mm}(1,73 \mathrm{in})$ ili penetracija zrnom pri brzini manjoj od najniže zadate u bilo kom testu, dovodi do odbacivanja prsluka po standardu NIJ 0101.04.

Zrno koje pogodi prsluk suviše blizu ivice ili prethodnom pogotku ili je registrovana suviše velika brzina zrna ali nije došlo do proboja, smatraće se ispravnim pogotkom sa aspekta penetracije.
Takođe, zrno koje udari većom brzinom od propisane, a pogodak je ispravan i iza prsluka proizvede otisak u plastelinu na dubini manjoj od $44 \mathrm{~mm}$ (1,73 in), smatra se ispravnim pogotkom u cilju određivanja deformacije.

\section{Ispitivanje penetracije i karakteri- stika plastelina za tipove prsluka I, II-A, II i III-A}

Rastojanje mereno od usta cevi za testiranje do udarne površine uzorka prsluka treba da iznosi $5 \mathrm{~m}(16,4 \mathrm{ft})$, uz dozvoljenu toleranciju od $\pm 25 \mathrm{~mm}( \pm 1,0$ in). Prsluk sa plastelinom treba postaviti tako da njegova prednja strana bude normalna na putanju zrna, tj. pod upadnim uglom od $0^{\circ}$.

Prvo zrno treba ispaliti tako da pogodi prsluk na mesto označeno sa \#1, kao što je prikazano na slici 5, koristeći hronograf za određivanje brzine zrna. Nakon toga treba pregledati prsluk i materijal za pozadinu, kako bi se utvrdilo da li je zrno napravilo ispravan pogodak i da li je došlo do penetracije.

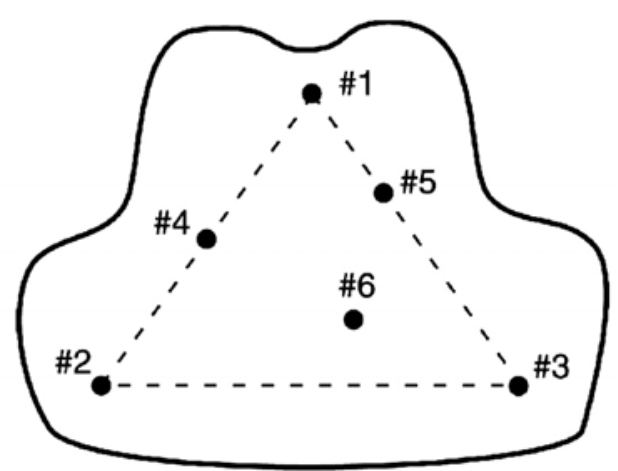

Sl. 5 - Raspored pogodaka na uzorku prsluka definisanih standardom NIJ 0101.04 
Ako nije došlo do proboja prsluka, a pogodak se smatra ispravnim, treba izmeriti i zabeležiti dubinu otiska koja je nastala u plastelinu. Ako je izmerena dubina otiska u skladu sa zahtevima standarda NIJ 0101.04, definisanim u koloni 6 tabele 2, prsluk ispunjava standard $i$ ispravan je za korišćenje.

Međutim, ako je dubina otiska veća od dopuštene, a izmerena brzina zrna premašuje za više od $15 \mathrm{~m} / \mathrm{s}(50 \mathrm{ft} / \mathrm{s})$ najnižu zahtevanu brzinu, plastelin treba ponovo kondicionirati, a prsluk izravnati i uraditi novo testiranje kako bi se dobio ispravan pogodak. Drugi pokušaj treba izvesti tako da se pogodi ista površina prsluka, ali za $51 \mathrm{~mm}$ (2 in) dalje od prethodnog pogotka i minimalno $76 \mathrm{~mm} \mathrm{(3}$ in) dalje od bilo koje ivice prsluka.

Ovaj postupak treba ponavljati sve dok se ne postigne ispravan pogodak, iza kojeg treba izmeriti dubinu otiska, kako bi se proverila saglasnost sa zahtevima standarda NIJ 0101.04.

Ukoliko nije bilo neispravnih pogodaka, prsluk treba staviti ponovo na materijal za pozadinu, i to bez ponovne primene plastelina (ne ravnati udubljenje nastalo od prethodnog pogotka) i bez uklanjanja zrna koje se zadržalo u prsluku. Brzine preostalih zrna, koja slede prema propisanom rasporedu, treba da ispune zahteve prikazane u tabeli 2 .

Pri sledećem gađanju treba pregledati prsluk da bi se uverili da je postignut ispravan pogodak. Ako nije, ispitivanje u istoj zoni prsluka treba ponoviti sve dok se ne postigne ispravan pogodak, a pre nego što se pređe na ispitivanje naredne lokacije prsluka.
Prsluk i materijal za pozadinu treba ponovo postaviti tako da po ispaljivanju drugo zrno pogodi prsluk na mesto označeno sa \# 2.

Bez remećenja odnosa između plastelina i prsluka (ne uklanjati zadržana zrna u prsluku i ne ravnati plastelin) treba opet postaviti elemente, tako da treće zrno pogodi prsluk na mestu označenom sa \#3.

Testiranje se nastavlja bez remećenja odnosa između prsluka i plastelina, a „delovi“ postavljaju tako da precizan upadni ugao između normale na prsluku i putanje leta zrna bude $30^{\circ}$, omogućavajući da četvrto zrno bude upućeno prema centralnom delu prsluka i pogodi prsluk na mestu označenom sa \# 4.

Peto zrno ispaljuje se pod istim uslovima kao četvrto zrno, osim da se prsluk pogodi na mestu označenom sa \# 5 .

Šesto zrno se, kao i kod ostalih, ispaljuje bez remećenja odnosa između prsluka i plastelina, s tim da se elementi prsluka postave tako da upadni ugao zrna bude $0^{\circ}$ i da prsluk bude pogođen na mestu označenom sa \# 6 .

Nakon završene prve serije test-pogodaka treba ispitati prsluk i plastelin da bi se ustanovilo da li je došlo do penetracije.

Prema izboru ispitivača, deo prsluka tipa I, II, II-A ili III-A, koji uspešno izdrži 6 ispravnih pogodaka sa jednom vrstom ispitne municije, može da bude testiran sa drugom opitnom municijom. Međutim, ako sa drugim tipom municije dođe do proboja prsluka, potrebno je izvršiti novo testiranje. 
Drugi uzorci prsluka biće ispitani drugom ispitnom municijom, a rezultati ovog ispitivanja smatraće se regularnim.

Prsluci tip I, II, II-A ili III-A, namenjeni da sadrže uklonive umetke za dopunsku balističku zaštitu ili zaštitu od traume na ograničenom delu prsluka, ispituju se bez dodatnog zaštitnog umetka.

Delove prsluka koji pokrivaju prsni i leđni deo torza, sa ili bez bočne zaštite, treba svaki put gađati predviđenim brojem ispravnih pogodaka koji je definisan u tabeli 2.

Pri testiranju prsluka namenjenih ženama pogoci na lokacijama 4 i/ili 5 treba da budu takvi da najmanje jedno zrno pogodi u korpu, pod upadnim uglom $30^{\circ}$. Ako korpe za grudi imaju jedan ili više šavova, zrno treba da pogodi u jedan šav.

Plastelin treba ponovo pripremiti $\mathrm{i}$ ponoviti postupak ispitivanja koji je opisan, koristeći test-zrno broj 2 iz tabele 2, a koje se zahteva za ispitivani tip prsluka. Ako nema više prostora na ovom prsluku, ponoviti ispitni postupak novim delom prsluka, koristeći drugu vrstu municije.

Ukoliko su prethodni postupci ispravni, celokupan postupak ispitivanja treba ponoviti kako je već opisano sa oba tipa zrna, koristeći nov uzorak prsluka.

\section{Penetracija i karakteristike plastelina pri testiranju prsluka tip III}

Rastojanje mereno od usta cevi za testiranje do udarne površine uzorka prsluka treba da iznosi $15 \mathrm{~m}(50 \mathrm{ft})$, uz dozvoljenu toleranciju od $\pm 25 \mathrm{~mm}$ ( $\pm 1,0 \mathrm{in})$.

Zadnja strana prsluka postavlja se tako da površinom dodiruje jednu površinu plastelina, a elementi se pričvršćuju pomoću dve vertikalne i tri horizontalne elastično-lepljive trake, tako da udarna strana prsluka ostane slobodna za ispitivanje.

Prsluci za ovaj tip zaštite najčešće su kruti i oblikovani tako da odgovaraju obliku ljudskog torza, pa njihova zadnja površina ne dolazi u kontakt sa površinom plastelina. Ovde je potrebno formirati zadnju stranu plastelina, tako da se dobije kontakt sa zadnjom stranom prsluka. Plastelin treba kondicionirati istovremeno sa osnovnim blokom plastelina i na isti način. Međutim, na ovaj nastavljeni plastelin ne mora da se izvede test sa čeličnim tegom.

Ovaj sklop treba postaviti tako da prednja strana prsluka bude normalna na putanju leta zrna, ispaliti jedan test-metak u prsluk i pri tom koristiti hronograf za određivanje brzine zrna. Zatim treba pregledati prsluk i plastelin, kako bi se odredilo da li je postignut ispravan pogodak $\mathrm{i}$ da li je došlo do penetracije ili cepanja.

Ako je pogodak ispravan prsluk se postavlja tako da se postigne još pet dodatnih pogodaka, po istim sekvencama kao kod testiranja vezanog za tip I, II-A, II, III-A, s tim da zrna pogode uzorak pod uglom od $0^{\circ}$ i da se ukupno dobije šest ispravnih pogodaka.

U slučaju da postoje šavovi na balističkom materijalu, željeni broj ispravnih pogodaka planira se tako da najmanje jedan bude ostvaren direktno u šav. Ako nije došlo do penetracije uzorka prsluka, potrebno je izmeriti i zabeležiti dubinu otiska u plastelinu za dva ispravna pogotka, vezanih za najveće izmerene brzine, i zabeležiti da li je dubina otiska u skladu sa zahtevima standarda NIJ 0101.04. 
Ukoliko nije bilo promašaja ili loših rezultata, celokupnu ispitnu proceduru treba ponoviti prema opisanom postupku za ispitivanje suvih prsluka.

\section{Penetracija i karakteristike plastelina} pri testiranju prsluka tip IV

Rastojanje mereno od usta cevi za testiranje do lica udarne površine uzorka prsluka treba da iznosi $15 \mathrm{~m}(50 \mathrm{ft})$, uz dozvoljenu toleranciju od $\pm 25 \mathrm{~mm}$ ( \pm 1,0 in). Zadnju stranu prsluka treba postaviti tako da površinom dodiruje jednu površinu plastelina i pričvrstiti elemente sa dve vertikalne i dve horizontalne elastično-lepljive trake, tako da udarna strana prsluka ostane slobodna za ispitivanje.

Ako je prsluk krut i oblikovan da odgovara ljudskom torzu, tako da zadnja strana prsluka ne može da dođe u kontakt sa površinom plastelina, na prednju stranu plastelina treba dodati onoliko gline koliko je potrebno da se postigne odgovarajući oblik i postigne kontakt sa zadnjom površinom prsluka. Plastelin treba da bude kondicioniran $\mathrm{u}$ isto vreme $\mathrm{i}$ na isti način kao osnovni (glavni) oblik plastelina.

Ovakav sklop postavlja se tako da prednja strana prsluka bude normalna na liniju putanje leta zrna, ispalljuje se jedan test-metak u prsluk i pri tom koristi hronograf za određivanje brzine zrna. Zatim se pregledaju prsluk i plastelin, kako bi se odredilo da li je postignut ispravan pogodak i da li je došlo do penetracije ili cepanja. U slučaju da nije došlo do proboja uzorka prsluka, izmeriti i zabeležiti dubinu otiska u plastelinu, a zatim proveriti da li je u skladu sa zahtevima standarda NIJ 0101.04.

Ukoliko je postignut ispravan pogodak, ponoviti celokupnu ispitnu proceduru prema sekvencama navedenim u postupku koji je propisan za ispitivanje prsluka tip I, II-A, II, III-A i III, s tim da zrna pogode uzorak pod uglom od $0^{\circ}$ i da se ukupno dobije šest ispravnih pogodaka.

Penetracija i karakteristike plastelina pri testiranju specijalnog tipa prsluka

Ako je prsluk u osnovi izrađen od tkanine, koristi se ispitni postupak primenjen za prsluke tip I, II-A, II i III-A. Ukoliko prsluk nije izrađen od tkanine, već je po samoj izradi krut ili čvrst (sadrži metalne ili keramičke ploče) treba koristiti ispitni postupak primenjen za prsluke tip III ili tip IV, što zavisi od konstrukcije prsluka koji se ispituje.

\section{Penetracija i karakteristike plastelina pri testiranju delova prsluka za zaštitu prepona i trtičnog dela}

Delove prsluka za zaštitu prepona i trtičnog dela treba gađati sa tri ispravna pogotka pod upadnim uglom od $0^{\circ}$. Deformacija se meri od prvog ispravnog pogotka radi provere ispravnosti pogotka. Nijedan pogodak zrna pri brzinama manjim od minimalno zahtevanih ne sme da probije prsluk.

\section{Označavanje zaštitnih prsluka}

Svaki set balistički otpornog prsluka treba da bude jasno i trajno označen (obeležen etiketom) čitljivim slovima, a svaki balistički paket treba da ima jednu etiketu.

Etiketa za balistički paket treba da sadrži sledeće podatke:

- naziv, logotip ili drugu oznaku za identifikaciju proizvođača; 
- procenjen nivo zaštite, pozivanje na određeno izdanje standarda (tip II u skladu sa NIJ-STD-0101.04);

- veličinu;

- broj partije (serije);

- datum isporuke;

- model ili oblik koji jedinstveno identifikuje paket radi nabavke (paketi označeni da odgovaraju muškom i ženskom torzu treba da imaju posebne oznake za model-oblik);

- udarna strana ili zadnja strana (površina) odeće, koja treba da bude izložena opasnosti ili da se nosi uz telo mora biti vidno obeležena;

- serijski broj;

- upustvo za održavanje balističkog materijala u skladu sa 16 CFR 423;

- za prsluk tip I do tipa III-A upozorenje treba da bude najmanje 15 puta veće od veličine ostalih slova na etiketi (izuzev potrebne informacije $u, a^{a}$ ) kojom se izjavljuje da prsluk nije namenjen za zaštitu od puščanih zrna;

- potvrda o saglasnosti sa standardom NIJ 0101.04. Prsluci sa balističkim paketima koji se ne uklanjaju moraju, pored etikete za balistički element, da poseduju etiketu na spoljnom plaštu koja je u skladu sa zahtevima za balističke pakete, osim ako je prsluk konstruisan tako da etiketa na balističkom paketu ne bude pokrivena plaštom.

Spoljni plašt sa zamenljivim paketima treba da ima etiketu (jednu ili više) na bilo kojoj spoljašnjoj strani. Ako je plašt iz jednog komada, tako da su svi delovi zajedno prošiveni u jednom komadu odeće, dovoljna je i jedna etiketa sa navedenim zahtevima.

Ako se prednja i zadnja strana plašta mogu razdvojiti, onda se etiketom označava i jedna i druga strana.
Etiketa za spoljni plašt treba da sadrži sledeće informacije:

- ime, logotip ili drugu oznaku proizvođača;

- izjavu kojom se korisniku saopštava da pogleda na balističke pakete da bi se utvrdio nivo zaštite;

- veličinu (ako kupcu odgovara, odobrenje za ime pojedinca za koga je prsluk napravljen);

- datum isporuke;

- model ili oznaku za oblik koji jedinstveno identifikuje paket radi nabavke (prsluk izrađen da odgovara muškom i ženskom torzu mora da ima odvojene oznake za model-oblik);

- vidno istaknute oznake na krajevima prsluka gde se balistički paneli završavaju, obeležavanjem šavova i postavljanjem natpisa „U OVOM DELU NEMA BALISTIČKE ZAŠTITE“, a balistička zaštita se omogućava preklapanjem prsluka na delu koji ne pokriva celokupan torzo (slika 6);

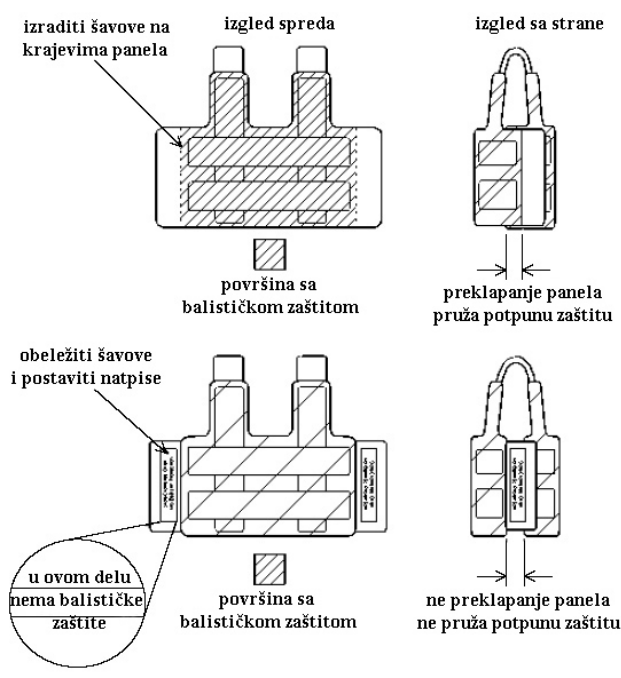

Sl. 6 - Označavanje zaštitnih prsluka 
- upustvo za održavanje za plašt prsluka u skladu sa propisom 16 CFR 423;

- certifikat o saglasnosti sa standardom NIJ-0101.04.

\section{Zaključak}

Svakodnevna izloženost opasnostima i uslovi primene oružja najrazličitijih vrsta i kalibara, kao i drugi akcidenti od sličnih sredstava, predstavljaju idealno polje za testiranje i utvrđivanje balističke otpornosti zaštitnih prsluka. Da bi se izbeglo testiranje u takvim situacijama, standard NIJ 0101.04 nudi najdetaljnije i najpouzdanije metode za ispitivanje u laboratoriji, omogućujući dobijanje relevantnih podataka o tačnoj balističkoj otpornosti zaštitnih prsluka.
Ujedno, ovaj standard predstavlja svojevrstan vodič za izbor odgovarajućeg tipa zaštitnog balističkog prsluka, ali i kada je potrebno da se u izvesnom stepenu pronađe kompromis između balističke zaštite i komfora pri nošenju.

Pre nabavke prsluka treba proučiti Vodič NIJ 100-01, „Selection and Applikation Guide to Personal Body Armor", koji opisuje suštinu problematike upotrebe zaštitnih prsluka.

Literatura:

[1] National Institute of Justice, NIJ Standard-0101.04, Ballistic Resistance of Police Body Armor, 2000.

[2] National Institute of Justice, NIJ Standard-0101.03, Ballistic Resistance of Police Body Armor, 1987.

[3] American National Standards Institute, ,SAAMI Z299.31993: Voluntary Industry Standards for Pressure and Velocity of Centerfire Pistol and Revolver Ammunition for the Use of Commercial Manufacturers," 1993.

[4] U. S. Army Test and Evaluation Command, TOP 2-2-710, Test Operations Procedure, Ballistic Tests of Armor Materials, 1999.

[5] Department of Defense, MIL-STD-662F, D o D Test Method Standard, V50 Ballistic Test for Armor, 1997. 